\title{
Front Matter: Volume 9434
}

, "Front Matter: Volume 9434," Proc. SPIE 9434, Nanosensors, Biosensors, and Info-Tech Sensors and Systems 2015, 943401 (5 May 2015); doi:

$10.1117 / 12.2184305$

Event: SPIE Smart Structures and Materials + Nondestructive Evaluation and Health Monitoring, 2015, San Diego, California, United States 


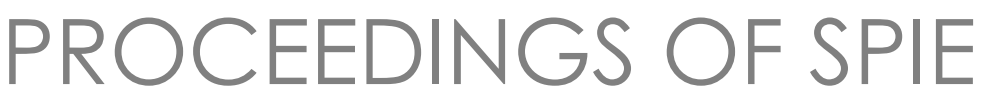

\title{
Nanosensors, Biosensors, and Info-Tech Sensors and Systems 2015
}

\author{
Vijay K. Varadan \\ Editor \\ 9-11 March 2015 \\ San Diego, California, United States \\ Sponsored by \\ SPIE \\ Cosponsored by \\ American Society of Mechanical Engineers (United States) \\ Cooperating Organizations \\ Intelligent Materials Forum (Japan) \\ Jet Propulsion Laboratory (United States) \\ National Science Foundation (United States) \\ Published by \\ SPIE
}


The papers included in this volume were part of the technical conference cited on the cover and title page. Papers were selected and subject to review by the editors and conference program committee. Some conference presentations may not be available for publication. The papers published in these proceedings reflect the work and thoughts of the authors and are published herein as submitted. The publisher is not responsible for the validity of the information or for any outcomes resulting from reliance thereon.

Please use the following format to cite material from this book:

Author(s), "Title of Paper," in Nanosensors, Biosensors, and Info-Tech Sensors and Systems 2015, edited by Vijay K. Varadan, Proceedings of SPIE Vol. 9434 (SPIE, Bellingham, WA, 2015) Article CID Number.

ISSN: 0277-786X

ISBN: 9781628415377

Published by

SPIE

P.O. Box 10, Bellingham, Washington 982270010 USA

Telephone +1 3606763290 (Pacific Time) · Fax +1 3606471445

SPIE.org

Copyright (C) 2015, Society of Photo-Optical Instrumentation Engineers.

Copying of material in this book for internal or personal use, or for the internal or personal use of specific clients, beyond the fair use provisions granted by the U.S. Copyright Law is authorized by SPIE subject to payment of copying fees. The Transactional Reporting Service base fee for this volume is $\$ 18.00$ per article (or portion thereof), which should be paid directly to the Copyright Clearance Center (CCC), 222 Rosewood Drive, Danvers, MA 01923. Payment may also be made electronically through CCC Online at copyright.com. Other copying for republication, resale, advertising or promotion, or any form of systematic or multiple reproduction of any material in this book is prohibited except with permission in writing from the publisher. The CCC fee code is 0277 $786 \mathrm{X} / 15 / \$ 18.00$.

Printed in the United States of America.

Publication of record for individual papers is online in the SPIE Digital Library.

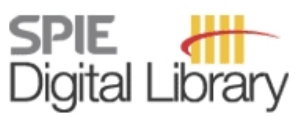

SPIEDigitalLibrary.org

Paper Numbering: Proceedings of SPIE follow an e-First publication model, with papers published first online and then in print. Papers are published as they are submitted and meet publication criteria. A unique citation identifier (CID) number is assigned to each article at the time of the first publication. Utilization of CIDs allows articles to be fully citable as soon as they are published online, and connects the same identifier to all online, print, and electronic versions of the publication. SPIE uses a six-digit CID article numbering system in which:

- The first four digits correspond to the SPIE volume number.

- The last two digits indicate publication order within the volume using a Base 36 numbering

system employing both numerals and letters. These two-number sets start with 00, 01, 02, 03, 04, $05,06,07,08,09,0 A, 0 B \ldots$. OZ, followed by 10-1Z, 20-2Z, etc.

The CID Number appears on each page of the manuscript. The complete citation is used on the first page, and an abbreviated version on subsequent pages. 


\title{
Contents
}

\author{
vii Authors \\ ix Conference Committee
}

\section{KEYNOTE SESSION I}

943402 Nano devices and concepts for condition-based maintenance of military systems (Keynote Paper) [9434-1]

\section{NANOSENSORS AND SYSTEMS I}

943403 A tactile sensor made of graphene-cellulose nanocomposite (Invited Paper) [9434-2]

943404 Design of an integrated sensor system for the detection of traces of different molecules in the air (Invited Paper) [9434-3]

\section{NANOSENSORS AND SYSTEMS II}

943406 Flexible pressure sensors for burnt skin patient monitoring (Invited Paper) [9434-5]

943408 Wireless nanosensors for monitoring concussion of football players [9434-7]

\section{NANO-AND MICRO-SYSTEMS IN MEDICINE AND HEALTHCARE}

943409 Probe-pin device for optical neurotransmitter sensing in the brain (Invited Paper) [9434-8]

9434 OA Nanosensor system for monitoring brain activity and drowsiness [9434-9]

$9434 \mathrm{OB} \quad$ Miniaturized neural sensing and optogenetic stimulation system for behavioral studies in the rat [9434-10]

9434 OC Effect of temperature and UV illumination on charge transport mechanisms in DNA [9434-45]

KEYNOTE SESSSION III

9434 OE Studying properties of RNA nanotubes via molecular dynamics [9434-13] 
9434 OG Cellulose nanocrystals, nanofibers, and their composites as renewable smart materials [9434-15]

$9434 \mathrm{OH} \quad$ Implementation and characterization of meta-resonator antennas (Invited Paper) [9434-16]

9434 Ol Efficient light scattering in plasmonic light trapping designs for thin film solar cells [9434-17]

9434 OJ Piezocomposites for unmanned underwater vehicle applications [9434-18]

\section{SPECIAL INVITED SESSION IN HONOR OF VASUNDARA VARADAN II}

9434 OK Cellulose/PDMS hybrid material for actuating lens (Invited Paper) [9434-19]

$9434 \mathrm{OL} \quad$ Novel design of honeycombs using a seamless combination of auxetic and conventional cores toward phononic band gap engineering (Invited Paper) [9434-20]

9434 OM Dynamics of plasmon in graphene oxide (Invited Paper) [9434-21]

\section{NANOSENSOR AND NANOCOMPOSITE}

$943400 \quad$ AC magnetic field-assisted method to develop porous carbon nanotube/conducting polymer composites for application in thermoelectric materials [9434-24]

9434 OR Study of nanosensor systems for hypertension associated cerebrovascular and cardiovascular disorders [9434-46]

\section{KEYNOTE SESSION IV: RF AND WIRELESS}

9434 OS RF to millimeter wave integration and module technologies (Keynote Paper) [9434-27]

9434 OT Review of radio wave for power transmission in medical applications with safety (Invited Paper) [9434-28]

\section{FABRICATION AND CHARACTERIZATION I}

9434 OU Enhanced electromechanical behaviors of cellulose ZnO hybrid nanocomposites [9434-29]

9434 OV 3D gel printing for soft-matter systems innovation [9434-30]

9434 OW The effects of width reduction on cantilever type piezoelectric energy harvesters [9434-31]

9434 OY Array haptic actuator for flight simulator [9434-33] 
FABRICATION AND CHARACTERIZATION II

$9434 \mathrm{OZ}$ Mechanoluminescence torque transducer integrated with cost-effective luminescence sensor and UV LEDs [9434-34]

943410 Synthesis of hybrid cellulose nanocomposite bonded with dopamine $\mathrm{SiO}_{2} / \mathrm{TiO}_{2}$ and its antimicrobial activity [9434-35]

943411 Synthesis and characterization of iron oxide-cellulose nanocomposite films [9434-36]

943412 Towards rhombohedral SiGe epitaxy on 150mm c-plane sapphire substrates [9434-37]

943413 Bismuth-induced surface structure and morphology in III-V semiconductors [9434-38]

POSTER SESSION

943414 Study on dynamic characteristics of smart composite laminates with partially debonded piezoelectric actuator [9434-39]

943417 Thin film of sol-gel deposited in photonic crystal fiber for cholesterol detection [9434-42]

943418 Simulation and experimental verification of flexible cellulose acetate haptic array actuator [9434-43] 
Proc. of SPIE Vol. $9434943401-6$

Downloaded From: https://www.spiedigitallibrary.org/conference-proceedings-of-spie on 26 Apr 2023 Terms of Use: https://www.spiedigitallibrary.org/terms-of-use 


\section{Authors}

Numbers in the index correspond to the last two digits of the six-digit citation identifier (CID) article numbering system used in Proceedings of SPIE. The first four digits reflect the volume number. Base 36 numbering is employed for the last two digits and indicates the order of articles within the volume. Numbers start with 00, 01, 02, 03, 04, 05, 06, 07, 08, 09, OA, OB...0Z, followed by 10-12, 20-2Z, etc.

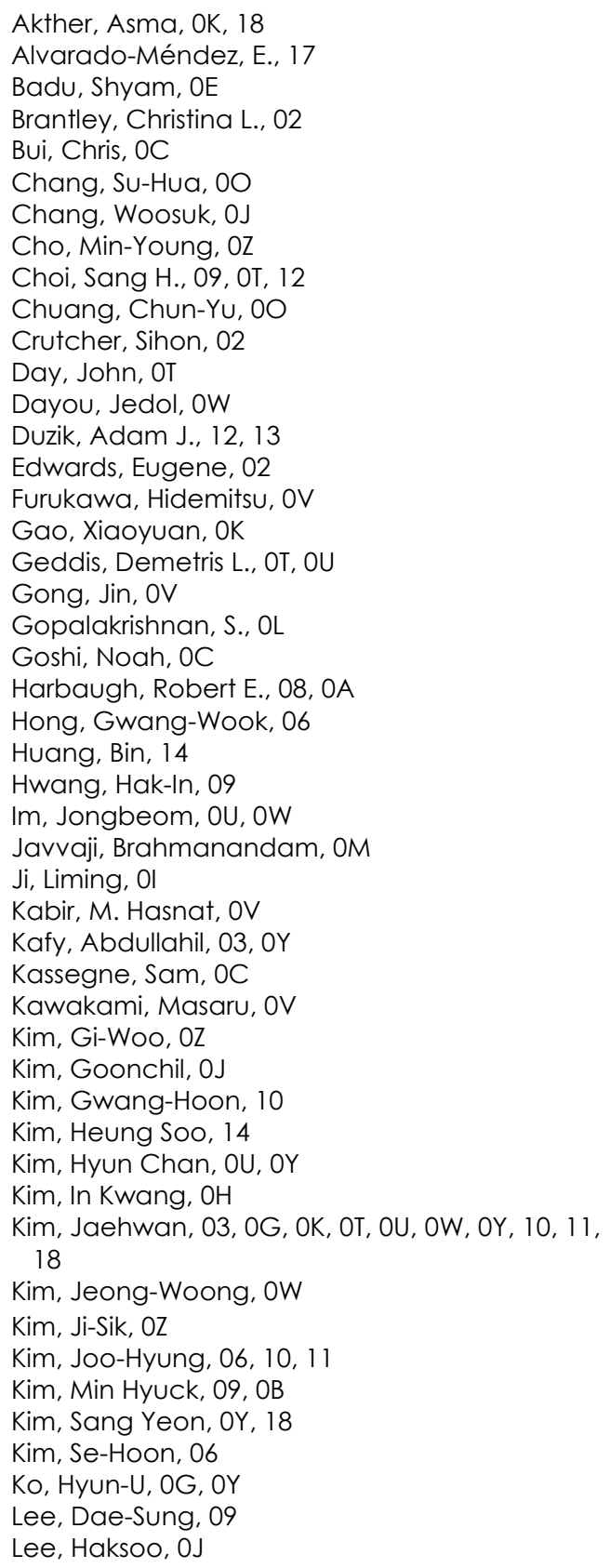

Lee, Uhn, 09

Mahapatra, D. Roy, OM

Makino, Masato, OV

Melnik, Roderick, OE

Min, Seung-Ki, OU, 18

Mohiuddin, Md, OK, 18

Mokili, John, OC

Mukherjee, Sushovan, OL

Mun, Seongcheol, 03, 0G, OK, OU, 11

Muševič, I., 04

Nam, llho, OB

Narenji, Alaleh Golkar, OC

Park, Yeonjoon, 09, 12

Prabhakar, Sanjay, OE

Raha, S., OM

Ramasamy, Mouli, 08, 0A, OR

Ramesh, Sivalingam, 10

Razo-Medina, D. A., 17

Ruffin, Paul B., 02

Ryu, Youngki, OB

Sadasivuni, Kishor Kumar, 03, OK

Saito, Azusa, OV

Sanford, Larry D., OB

Scarpa, Fabrizio, OL

Seo, Heesul, OJ

Shin, Hoseop, 0J

Shin, Kyu-Sik, 09

Song, Kyo D., 09, 0T

Strle, D., 04

Trejo-Durán, M., 17

Vähä-Heikkilä, T., OS

Varadan, Vasundara $\mathrm{V} ., \mathrm{OH}, \mathrm{Ol}$

Varadan, Vijay K., 08, OA, OR

Wellman, Laurie W., OB

Yadav, Mithilesh, 11

Yang, Shu-Chian, 00

Yang, Ta-l, 00

Yoon, Gil Ho, 14

Yoon, Hargsoon, 09, OB, ОT

Yun, Jong-Hwan, $\mathrm{OZ}$

Yun, Young-Min, OG

Zhai, Lindong, OG, OW 
Proc. of SPIE Vol. $9434943401-8$

Downloaded From: https://www.spiedigitallibrary.org/conference-proceedings-of-spie on 26 Apr 2023 Terms of Use: https://www.spiedigitallibrary.org/terms-of-use 


\title{
Conference Committee
}

\author{
Symposium Chairs
}

Victor Giurgiutiu, University of South Carolina (United States)

Christopher S. Lynch, University of California, Los Angeles

(United States)

Symposium Co-chairs

Jayanth N. Kudva, NextGen Aeronautics, Inc. (United States)

Theodoros E. Matikas, University of loannina (Greece)

Conference Chair

Vijay K. Varadan, The Pennsylvania State University (United States)

Conference Co-chairs

Jaehwan Kim, Inha University (Korea, Republic of)

Kyo D. Song, Norfolk State University (United States)

Sang H. Choi, NASA Langley Research Center (United States)

Conference Program Committee

Anja Boisen, Technical University of Denmark (Denmark)

Christina L. Brantley, U.S. Army Research, Development and

Engineering Command (United States)

Natalie Clark, NASA Langley Research Center (United States)

Dileepan Joseph, University of Alberta (Canada)

Sam Kassegne, San Diego State University (United States)

Ajit Khosla, Concordia University (Canada)

Kimiya Komurasaki, The University of Tokyo (Japan)

Kunik Lee, Federal Highway Administration Turner Fairbank Highway

Research Center (United States)

Samuel C. Lee, The University of Oklahoma (United States)

Uhn Lee M.D., Gachon University Gil Medical Center

(Korea, Republic of)

Xinxin Li, Shanghai Institute of Microsystem and Information

Technology (China)

Yanjian Liao, Chongqing University (China)

Ilkwon Oh, KAIST (Korea, Republic of)

Yeonjoon Park, National Institute of Aerospace (United States)

Parag G. Patil, University of Michigan Health System (United States)

Aswini K. Pradhan, Norfolk State University (United States)

D. Roy Mahapatra, Indian Institute of Science (India) 
Ashok Srivastava, Louisiana State University (United States)

Tauno Vaha-Heikkila, VTT Technical Research Centre of Finland

(Finland)

Wei-Chih Wang, University of Washington (United States)

Richard K. Watt, Brigham Young University (United States)

T. C. Yih, California State University, Long Beach (United States)

Hargsoon Yoon, Norfolk State University (United States)

Ming Zhou, Suzhou Institute of Nano-tech and Nano-bionics (China)

\section{Session Chairs}

Keynote Session I

Vijay K. Varadan, The Pennsylvania State University (United States)

Nanosensors and Systems I

Vijay K. Varadan, The Pennsylvania State University (United States)

Keynote Session II

Sang H. Choi, NASA Langley Research Center (United States)

Nanosensors and Systems II

Hargsoon Yoon, Norfolk State University (United States)

Nano-and Micro-systems in Medicine and Healthcare

Hyun Jung Kim, National Institute of Aerospace (United States)

Keynote Sesssion III

Kyo D. Song, Norfolk State University (United States)

Special Invited Session in honor of Vasundara Varadan I

Eugene Edwards, U.S. Army Research, Development and Engineering Command (United States)

Special Invited Session in honor of Vasundara Varadan II

Vijay K. Varadan, The Pennsylvania State University (United States)

In Kwang Kim, Nextivity, Inc. (United States)

Nanosensor and Nanocomposite

Eugene Edwards, U.S. Army Research, Development and Engineering Command (United States)

Keynote Session IV: RF and Wireless

Sang H. Choi, NASA Langley Research Center (United States)

Fabrication and Characterization I

Jaehwan Kim, Inha University (Korea, Republic of) 
Fabrication and Characterization II

Sang H. Choi, NASA Langley Research Center (United States)

Proc. of SPIE Vol. $9434943401-11$

Downloaded From: https://www.spiedigitallibrary.org/conference-proceedings-of-spie on 26 Apr 2023 Terms of Use: https://www.spiedigitallibrary.org/terms-of-use 
Proc. of SPIE Vol. $9434943401-12$

Downloaded From: https://www.spiedigitallibrary.org/conference-proceedings-of-spie on 26 Apr 2023 Terms of Use: https://www.spiedigitallibrary.org/terms-of-use 